\title{
Threatened amphibians in the former Soviet Union: the current situation and the main threats
}

\author{
Sergius L. Kuzmin
}

Before the dissolution of the USSR in 1991, research and conservation of the region's amphibian fauna was co-ordinated by a network of scientists. The use of similar survey methods made it possible to obtain comparable estimates of amphibian populations in different parts of the territory. Since 1991 the system of research and conservation has broken down as a result of political changes and economic crisis. The scientific community has become fragmented and there is a scarcity of funds available for essential research and conservation. There is an urgent need for the adoption and implementation of conservation measures, both within the territory of the former USSR and elsewhere, in order to prevent further declines in threatened amphibian populations. This paper presents a summary of the status of amphibians in the former USSR, the threats they face and recommended measures to protect them.

The amphibian fauna of the former USSR consists of 41 species. Among these, the following were included in the last edition of the Red Data Book of USSR (Borodin, 1984): salamanders - Ranodon sibiricus, Onychodactylus fischeri, Mertensiella caucasica, Triturus vittatus, T. montandoni and T. alpestris; toads - Pelobates syriacus, Pelodytes caucasicus and Bufo calamita. All these species and some others were included in the Red Data Books of various Soviet Republics (Table 1).

All the Red Data Book species were more or less effectively protected in the USSR as a whole and in each Republic in particular. Now that each former Soviet Republic is an independent state, the former system of nature protection is redundant and the former Red Data Book of USSR no longer operates. In addition, since the publication of the last editions of Red Data Books in the former Soviet Republics, many new ecological and taxonomic data concerning amphibians have been published. This has made it necessary to devise a new system for defining the conservation status of amphibians. This system is proposed in Table 2. The categories of status used are in accordance with the former IUCN system because the new IUCN system of quantified criteria (adopted in 1994) is inapplicable to amphibians of the former Soviet Union. There are not enough data to estimate changes in populations throughout their ranges in strict quantified terms. The status of some species (not included in Table 2, e.g. Bufo raddei, Hyla arborea and Rana temporaria) are of local concern but not on a region-wide basis. These are not discussed here. In addition, an enigmatic hynobiid, the Turkestanian salamander Hynobius turkestanicus, which is known only by its original description, also appears to be threatened. Some subspecies also deserve inclusion in Red Data Books of different levels, such as the newt Triturus vulgaris lantzi, the toad Bufo viridis asiomonatanus and the frog Rana arvalis wolterstorffi (the latter two are not included in Tables 1 or 2). Thus some additions to the republican Red Data Books appear to be necessary (see Table 2).

The current planning of the inter-republican Red Data Book of the Commonwealth of Independent States (CIS), which should be analogous to the Red Data Book of the USSR, 
Table 1. Amphibian species occurring in the former Soviet Union showing current and proposed listings in the Red Data Books of the individual republics and the proposed status in the new Red Data Book of the CIS

\section{Republics}

Species

Li. La. Es. Be. Mo. Uk. Ru. Ge. Ar. Az. Tu. Uz. Ta. Ka. Ki. CIS

\begin{tabular}{|c|c|c|c|c|c|c|c|c|c|c|c|c|c|c|c|c|}
\hline \multicolumn{17}{|l|}{ Salamandrella } \\
\hline keyserlingii & - & - & - & - & - & - & + & - & - & - & - & - & - & $\mathrm{L}^{*}$ & - & - \\
\hline Ranodon sibiricus & - & - & - & - & - & - & - & - & - & - & - & - & - & $\mathrm{L}$ & - & $\mathrm{V}$ \\
\hline Onychodactylus & & & & & & & & & & & & & & & & \\
\hline fischeri & - & - & - & - & - & - & $\mathrm{L}$ & - & - & - & - & - & - & - & - & $\mathrm{R}$ \\
\hline Salamandra & & & & & & & & & & & & & & & & \\
\hline salamandra & - & - & - & - & - & $\mathrm{L}$ & - & - & - & - & - & - & - & - & - & $\mathrm{R}$ \\
\hline Mertensiella & & & & & & & & & & & & & & & & \\
\hline caucasica & - & - & - & - & - & - & - & $\mathrm{L}$ & - & - & - & - & - & - & - & $\mathrm{R}$ \\
\hline Triturus vulgaris & & & & & & & & & & & & & & & & \\
\hline lantzi & - & - & - & - & - & - & $\mathrm{L}^{*}$ & $\mathrm{~L}^{*}$ & - & $\mathrm{L}^{*}$ & - & - & - & - & - & I \\
\hline Triturus vittatus & - & - & - & - & - & - & $\mathrm{L}$ & $\mathrm{L}$ & - & - & - & - & - & - & - & $\mathrm{I}$ \\
\hline Triturus & & & & & & & & & & & & & & & & \\
\hline montandoni & - & - & - & - & - & $\mathrm{L}$ & - & - & - & - & - & - & - & - & - & $\mathrm{R}$ \\
\hline Triturus alpestris & - & - & - & - & - & $\mathrm{L}$ & - & - & - & - & - & - & - & - & - & $\mathrm{R}$ \\
\hline Triturus cristatus & $\mathrm{L}^{*}$ & $\mathrm{~L}$ & $\mathrm{~L}^{*}$ & + & + & + & + & - & - & - & - & - & - & - & - & - \\
\hline Triturus dobrogicus & - & - & - & - & - & $\mathrm{L}^{*}$ & - & - & - & - & - & - & - & - & - & $\mathrm{R}$ \\
\hline Triturus karelinii & - & - & - & - & - & $\mathbf{L}^{*}$ & $\mathrm{~L}^{*}$ & $\mathrm{~L}^{*}$ & - & L & - & - & - & - & - & I \\
\hline Bombina bombina & - & $\mathrm{L}$ & - & + & + & + & + & - & - & - & - & - & - & + & - & - \\
\hline Pelobates fuscus & $\mathrm{L}^{*}$ & $\mathrm{~L}^{*}$ & $L^{*}$ & + & $\mathrm{L}^{*}$ & + & + & - & - & - & - & - & - & + & - & - \\
\hline Pelobates syriacus & - & - & - & - & - & - & $\mathrm{L}$ & $\mathrm{L}$ & $\mathrm{L}$ & $\mathbf{L}$ & - & - & - & - & - & $\mathrm{R}$ \\
\hline Pelodytes caucasius & - & - & - & - & - & - & $\mathrm{L}$ & $\mathrm{L}$ & - & $\mathbf{L}$ & - & - & - & - & - & $\mathrm{R}$ \\
\hline Bufo verrucosissimus & - & - & - & - & - & - & $\mathrm{L}^{*}$ & $\mathrm{~L}^{*}$ & - & $\mathbf{L}$ & - & - & - & - & - & $\mathrm{R}$ \\
\hline Bufo viridis & + & + & $\mathrm{L}^{*}$ & + & + & + & + & + & + & + & + & + & + & + & + & - \\
\hline Bufo danatensis & - & - & - & - & - & - & - & - & - & - & $\mathrm{L}^{*}$ & + & + & + & + & - \\
\hline Bufo calamita & $\mathbf{L}$ & $\mathrm{L}$ & $\mathrm{L}$ & $\mathrm{L}$ & - & $\mathrm{L}$ & $\mathrm{L}$ & - & - & - & - & - & - & - & - & $\mathrm{I}$ \\
\hline Hyla arborea & $\mathbf{L}$ & $\mathrm{L}$ & - & + & + & + & + & + & + & + & - & - & - & - & - & - \\
\hline Hyla savignyi & - & - & - & - & - & - & - & $\mathrm{L}^{*}$ & $\mathrm{~L}^{*}$ & $\mathrm{~L}^{*}$ & - & - & - & - & - & $\mathrm{I}$ \\
\hline Rana temporaria & + & + & + & + & + & + & + & - & - & - & - & - & - & $\mathrm{L}^{*}$ & - & - \\
\hline Rana dalmatina & - & - & - & - & - & $\mathbf{L}$ & - & - & - & - & - & - & - & - & - & $\mathrm{R}$ \\
\hline Rana macrocnemis & - & - & - & - & - & - & + & + & + & + & $\mathbf{L}$ & - & - & - & - & - \\
\hline Rana asiatica & - & - & - & - & - & - & - & - & - & - & - & - & - & $\mathrm{L}$ & $L^{*}$ & I \\
\hline Rana ridibunda & - & $\mathrm{L}^{*}$ & $\mathrm{~L}^{*}$ & + & + & + & + & + & + & + & + & + & + & + & + & - \\
\hline Rana lessonae & + & $\mathrm{L}^{*}$ & $\mathrm{~L}^{*}$ & + & + & + & + & - & - & - & - & - & - & - & - & - \\
\hline Rana kl. esculenta & $\mathrm{L}^{*}$ & $L^{*}$ & $L^{*}$ & $L^{*}$ & - & + & + & - & - & - & - & - & - & - & - & - \\
\hline Rana terentievi & - & - & - & - & - & - & - & - & - & - & - & - & $\mathrm{L}^{*}$ & - & - & I \\
\hline Rana nigromaculata & - & - & - & - & - & - & + & - & - & - & $\mathrm{L}^{*}$ & - & - & - & - & - \\
\hline
\end{tabular}

Li., Lithuania; La., Latvia; Es., Estonia; Be., Belorussia; Mo., Moldavia; Uk., Ukraine; Ru., Russia; Ge., Georgia; Ar., Armenia; Az, Azerbaijan; Tu., Turkmenia; Uz., Uzbekistan; Ta., Tajikistan; Ka., Kazakhstan; Ki., Kirgizia. The CIS includes all these republics except the three Baltic states: Lithuania, Latvia and Estonia.

I, Indeterminate; R, Rare; V, Vulnerable; L, existing listing; $\mathrm{L}^{*}$, proposed listing; +, not threatened;--, absent,

Sources: Iskakova, 1959; Szczerbak, 1966; Alekperov, 1978; Szczerbak and Szczerban, 1980; Pikulik, 1985; Gruodis et al., 1986; Darevsky and Krever, 1987; Orlova and Tuniyev, 1989; Mezhzherin, 1992; Talvi, 1992; author's unplublished data.

Species not included in the table: Hynobius turkestanicus (unknown status); Triturus v. vulgaris, Bombina orientalis, B. variegata, Bufo bufo, B. gargarizans, B. raddei, Hyla japonica, Rana arvalis, R. amurensis, R. dybowskii and $R$. ridibunda (these species were neither included nor proposed for inclusion in the Red Lists of any of the republics).

(C) $1996 \mathrm{FFI}$, Oryx, 30 (1), 24-30 
Table 2. Amphibian species of threatened and uncertain status in Republics of the former Soviet Union

Republics

Species

Li. La. Es. Be. Mo. Uk. Ru. Ge. Ar. Az. Tu. Uz. Ta. Ka. Ki.

Hynobius turkestanicus

Salamandrella keyserlingii

Ranodon sibiricus

Onychodactylus fischeri

Salamandra salamandra

Triturus vulgaris vulgaris

Triturus vulgaris lantzi

Triturus vittatus

Triturus montandoni

Triturus alpestris

Triturus cristatus

Triturus dobrogicus

Triturus karelinii

Bombina bombina

Bombina orientalis

Pelobates fuscus

Pelobates syriacus

Pelodytes caucasius

Bufo bufo

Bufo verrucosissimus

Bufo viridis

Bufo danatensis

Bufo calamita

Hyla arborea

Hyla savignyi

Rana temporaria

Rana arvalis

Rana dalmatina

Rana macrocnemis

Rana asiatica

Rana lessonae

Rana kl. esculenta

Rana ridibunda

Rana terentievi

Rana nigromaculata

Li. La. Es. Be. Mo. Uk. Ru. Ge. Ar. Az. Tu. Uz. Ta. Ka. Ki.

Li., Lithuania; La., Latvia; Es., Estonia; Be., Belorussia; Mo., Moldavia; Uk., Ukraine; Ru., Russia; Ge., Georgia; Ar., Armenia; Az, Azerbaijan; Tu., Turkmenia; Uz., Uzbekistan; Ta., Tajikistan; Ka., Kazakhstan; Ki., Kirgizia.

K, Insufficiently known; I, Indeterminate; R, Rare; V, Vulnerable; E, Endangered; Ex, Extinct' + , not threatened; - , absent.

Sources: Iskakova, 1959; Szczerbak, 1966; Alekperov, 1978; Szczerbak and Szczerban, 1980; Pikulik, 1985; Gruodis et al., 1986; Darevsky and Krever, 1987; Orlova and Tuniyev, 1989; Mezhzherin, 1992; Talvi, 1992; author's unpublished data.

See Table 1 for species not included. 
is an important step in the co-operation of the republics in amphibian protection. The new Red Data Book will include only those species listed in the Red Data Books of the individual republics, so the changes indicated in Table 1 need to be made urgently. An inter-republican committee for the preparation of the new Red Data Book will be created in the near future. It should be noted, however, that the Red Data Book of the CIS will not be a full analogue of the Red Data Book of the USSR because the CIS differs from the USSR by the lack of the three Baltic Republics (Lithuania, Latvia and Estonia). The species that will be included in the Red Data Book of CIS must be of conservation concern in the CIS territory as a whole. The species discussed below may be proposed for inclusion in this list (see Table 1 for status).

Ranodon sibiricus (Kessler, 1866), the Semirechensk salamander, inhabits a restricted area in Junggarian Alatau and Borokhoro ridges in southern Kazakhstan and north-western China at 1450-2500 m (Brushko et al., 1988). Its distribution is associated mainly with small brooks in the relict mountain coniferous forest belt, but in places with suitable precipitation it also lives in meadows. Population density in suitable sites varies from 1.6 to 62 animals per $100 \mathrm{~m}$ of stream bank (Brushko et al., 1988). The species appears to decline as a result of deforestation, habitat destruction by cattle, drainage works for agriculture, collecting for commercial and scientific purposes, and the local practice of fishing by diverting streams (Kuzmin, 1994). Simplification of the regulations governing the Kazakhstan-Chinese border and the opening of formerly closed frontier areas in the Junggarian Alatau also create a potential threat for this species due to its use in traditional Chinese medicine. It is the only Red Data Book species that does not occur in a protected area.

Onychodactylus fischeri (Boulenger, 1886), the long-tailed clawed salamander, occurs in Russia, Korea and eastern China. The species has its northernmost range in Russia: the Sikhote-Alin Mountains and Pogranichny
Ridge in southern Primorye. This highly specialized, lungless species is adapted to cold, small mountain streams with wet banks in mixed forests. In suitable sites, the population density may reach few adults per $10 \mathrm{sq}$ $\mathrm{m}$, but downstream the population density decreases because of increased water temperature and the presence of predatory fish (Kuzmin, 1995). Anthropogenic pressure on populations appears to be relatively low, but the populations are vulnerable even to slight habitat changes.

Salamandra salamandra (Linnaeus, 1758), the spotted salamander, is distributed from eastern Europe to the Middle East and north-west Africa. In the former Soviet Union it lives only in the Ukraine. There it is found in the mountain forest zone of the Carpathians at 150-1500 $\mathrm{m}$, in wet and dense deciduous, mixed or, rarely, coniferous forests (Szczerbak and Szczerban, 1980). In suitable sites the density of adults reach $45-50$ individuals per sq $\mathrm{km}$ but it is usually much lower (Szczerbak and Szczerban, 1980). Pollution, habitat destruction, and collecting for commercial purposes are the main threats (Kuzmin, 1994).

Mertensiella caucasica (Waga, 1876), the Caucasian salamander, has a small range in the former USSR (western Georgia) and adjacent parts of Turkey at altitudes of 50-2800 m, near cold streams in mixed and coniferous forests and subalpine meadows. Up to $c .14$ specimens may be captured during night excursions in mid-summer along $10 \mathrm{~m}$ of stream bank (Tarkhnishvili and Serbinova, 1993); larval density is no more than one specimen per 2 litres of water (Kuzmin, 1992). The species is generally rare and vulnerable to changes in habitat. Many populations are endangered by anthropogenic influences, including habitat pollution and destruction but especially the practice of using water courses to transport logs (Kuzmin, 1994).

Triturus vulgaris lantzi (Wolterstorff, 1914), Lantz's smooth newt, is endemic to the mountain forest of Caucasus $(1300-2700 \mathrm{~m})$ in Turkey and the former USSR (Russia, Georgia 
and Azerbaijan; Gorovaya and Tertyshnikov, 1983). Deforestation is the main threat but the newt is sometimes collected for commercial trade.

Triturus vittatus (Jenyns, 1835), the banded newt, occurs in Israel, Asia Minor and the western Caucasus. In Caucasus (Russia and Georgia), it lives only in the forest of the foothills and mountains up to subalpine meadows, at $0-2750 \mathrm{~m}$ (Borodin, 1984). Habitat destruction and overcollecting appear to be the main threats.

Triturus montandoni (Boulenger, 1860), the Carpathian newt, is endemic to the Carpathian Mountains. In the Ukrainian Carpathians it occurs in the forest and subalpine zones at 150-2000 m (Szczerbak and Szczerban, 1980). Although local densities are high, this species has a narrow range and is rare overall. Some populations have declined because of habitat destruction and high larval and embryonic mortality in traffic ruts on country roads (Kuzmin, 1994).

Triturus alpestris (Laurenti, 1768), the alpine newt, occurs in Europe east to the Ukrainian Carpathians, the only area where it is found in the former USSR. It occurs there primarily at $300-2000 \mathrm{~m}$, in wet, shady coniferous, mixed and deciduous forests, and subalpine meadows (Szczerbak and Szczerban, 1980). It is rarer than the Carpathian newt. Some populations are declining, mainly because of habitat destruction (Kuzmin, 1994).

Triturus dobrogicus (Kiritzescu, 1903), the Danube crested newt, inhabits only valleys in the Danube River system. In the Ukraine, it is restricted to the Danube River delta and Transcarpathian Plain. Its distribution and ecology are poorly known (see Szczerbak and Szczerban, 1980).

Triturus karelinii (Strauch, 1870), the southern crested newt, occurs in the eastern part of the Balkan Peninsula, Crimea (Ukraine), Asia Minor, Caucasus (Russia, Georgia and Azerbaijan), and northern Iran. It lives only in wet, mixed mountain forests and their surroundings at $50-2200 \mathrm{~m}$. Some populations are declining because of anthropogenic influences, including forest destruction and pollution, especially in Crimea and Azerbaijan (Szczerbak, 1966; Kuzmin, 1994).

Pelobates syriacus (Boettger, 1889), the eastern spadefoot toad, occurs in the Middle East, Asia Minor, Balkan Peninsula and all the former Soviet Republics of Caucasus. In the Caucasus the species is sporadically distributed at $0-1900 \mathrm{~m}$ on riverbanks with dense herbaceous vegetation. The overall population numbers appear to be low. Droughts sometimes lead to mass adult mortality (Alekperov, 1978). The Caucasian populations appear to decline with the anthropogenic destruction of habitats.

Pelodytes caucasicus (Boulenger, 1896), the Caucasian parsley frog, occurs only in western Caucasus (Russia, Georgia and Azerbaijan) from the northern mountain slopes to northern Turkey at $10-2300 \mathrm{~m}$, in mountain forests and alpine meadows, usually near ponds and streams. Although the size of some populations reaches 10000 individuals (Golubev, 1985), the distribution is sporadic. In general, the frog is more numerous in the northern Caucasus than in Transcaucasia (Golubev, 1985).

Bufo verrucosissimus (Pallas, 1811), the Caucasian toad, occurs in western Caucasus on the northern and southern slopes of the Main Caucasian Ridge in Russia, Georgia and Azerbaijan. The toad lives in wet mountain forests and scrub, as well as on their edges and in glades (Orlova and Tuniyev, 1989). Population density is $0.1-1360$ individuals per ha (Khonyakina, 1953; Vysotin and Tertyshnikov, 1988). However, generally, numbers appear to be low due to the restricted range and the small amount of suitable habitat. Deforestation is the main threat.

Bufo calamita (Laurenti, 1768), the natterjack toad, is widely distributed in Europe towards the west of the former USSR: Kaliningrad 
Province of Russia, the Baltic Republics, western Ukraine, and Belorussia. It lives there in sand dunes, pine forest glades and gardens. Population numbers are generally low (Pikulik, 1985; Gruodis et al., 1986). Many populations are declining because of anthropogenic pressure, primarily habitat destruction.

Hyla savignyi (Audouin, 1827), the lemon-yellow tree frog, occurs in Asia Minor, the Middle East, Egypt and some southern Transcaucasian areas in Georgia, Armenia and Azerbaijan, in steppes, deserts and semideserts (Alekperov, 1978). Its distribution and biology are poorly known.

Rana dalmatina (Bonaparte, 1840), the agile frog, is a European species. In the former USSR, it is known only from the Ukraine on the Transcarpathian Plain and adjacent foothills and mountain slopes (0-950 m), in broadleaved forests with sparse tree cover (Szczerbak and Szczerban, 1980). It is relatively common only in a few localities: 100-150 individuals per ha (Szczerbak and Szczerban, 1980).

Rana terentievi (Mezhzherin, 1992), Terentjev's frog, is known only from its description from the Obi-Garm Settlement, Komsomolabad District, southern Tajikistan (Mezhzherin, 1992). It probably also occurs in the lower reaches of the Amu-Darya River and in northern Afghanistan. Its biology is unknown and it is unlikely to be studied in the near future due to civil war in southern Tajikistan.

\section{Future prospects for amphibians}

What are the prospects for amphibians in the CIS? The situation regarding the production of Red Data Books is uncertain almost everywhere. There is inadequate legislation, and even where it exists poor enforcement means that laws are widely violated in the former USSR, in Russia in particular. Destruction and pollution of habitats and the illegal occupation of reserve lands are widespread.
Due to increasing divergence of incomes in an increasingly stratified society, to the increasing price differentials between the CIS and abroad and to the relaxation of border controls, collecting and trade in amphibians and reptiles has become one of the most profitable businesses in the former USSR.

Today it is not always possible to distinguish between legal and illegal trade and it is also much more difficult to control legal trade. Only a few facts and anecdotal information are available. There are a few companies and many individual dealers in different republics who are involved in the trade in herpetofauna. Any citizen of a former Soviet republic is free to go to an area with threatened amphibians and to collect and export them to the republic with the most lenient trade and export controls. In addition, some local people collect animals and send them to dealers. The main centres of such trade, which is aimed mainly at markets in western Europe and the USA, are in Moscow, Tula, Kharkov, Kiev and the Baltic states. Some media report that Russia has become the main world exporter of amphibians and reptiles for terraria. The majority of amphibians are caught in Caucasus and Carpathians (areas with the majority of threatened species) but also in the Russian Far East and elsewhere. Many reptiles and some amphibians, even from Vietnam, are regularly exported to Russia and on to other countries.

Salamanders are very attractive to dealers. According to anecdotal information, in the early 1980 s at least $200 \mathrm{M}$. caucasica were exported annually, mainly to dealers in western Europe for sale as terrarium pets. In the late 1980 s about 30 individuals of $R$. sibiricus were illegally caught and exported. In 1982-83, T. vittatus were freely available from pet shops in Erevan, Armenia. In the 1990s this species was caught in massive numbers in Georgia, mainly for trade elsewhere. Now it is collected regularly every year in the Krasnodar Region, northern Caucasus, for example near the cities of Guzeripl and Maikop, which has led to the decline of some populations. Each spring, at least a few hundred individuals of this newt are sold in pet markets in Moscow and Sochi 
and in smaller numbers in other cities, for example Rostov-na-Donu and Tbilisi. It is estimated that almost the same numbers die during transport and in temporary holding facilities. Triturus karelini, T. vulgaris lantzi, T. montandoni, $T$. alpestris and $S$. salamandra are caught in comparable numbers but less regularly. The recent civil wars in the Caucasus have significantly reduced amphibian collecting there, especially by foreigners.

All these data reflect the tip of the iceberg. Real illegal purchases must be many times higher. Effective control of this trade in the former USSR seems to be impossible now. International efforts, at least to prevent export of threatened amphibians to the West are of immediate need. Western countries, especially the European Community and the USA, should adopt special regulations to prevent illegal import of threatened species from the former Soviet Union. For example, it may be necessary to establish strict requirements for certificates of species identification, to confiscate threatened species that are exported illegally or with false certificates, and to penalize heavily local companies that conduct such trade with the former USSR.

\section{Acknowledgement}

I thank the Russian Foundation of Fundamental Research (Grant no. 95-04-11092) for support of this work.

\section{References}

Alekperov, A.M. 1978. Zemnovodnye i Presmykayushchisya Azerbaijana. Elm, Baku.

Borodin, A.M. (ed.) 1984. Krasnaya Kniga SSSR. Vol. 1. Lesanya Promyshlennost, Moscow.

Brushko, Z.K., Kubykin, R.A. and Narbaeva, S.P. 1988. Recent distribution of Siberian salamander Ranodon sibiricus (Amphibia, Hynobiidae) in Dzungar Alatau. Zoologichesky Zhurnal, 67, 1753-1756.

Darevsky, I.S. and Krever, V.G. (eds). 1987. Amfibii i Reptilii Zapovednykh Territorii. TsNIL, Moscow.

Golubev, N.S. 1985. Kavkazskaya Krestovka Pelodytes caucasicus Boulenger (Pelodytes (caucasicus). PhD thesis, USSR Acad. Sci, Leningrad.

Gorovaya, V.I. and Tertyshnikov, M.V. 1983. On the biology of Trituris vulgaris lantzi Wolt., 1914, in central pre-Caucasica. In Vid i Ego Produktionost v
Areale, pp. 8-92. Nauka, Moscow.

Gruodis, S., Caune, I. and Vilnitis, V. 1986. Present situation of the investigation of running toad (Bufo calamita Laur) in the Eastern Baltics. In Okhrana, Ekologiya $i$ Etologiya Zhivotnykh, pp. 73-96. Riga.

Iskakova, K. 1959. Zemnovodnye Kazakhstana. Inst. Zool. Acad. Sci. of Kazakh SSR. Alma-Ata.

Khonyakina, Z. 1953. Materials on biology of Bufo bufo verrucosissimus of the Caucasian Natural Reserve, Zoologichesky Zhurnal, 32, 1193-1197.

Kuzmin, S.L. 1992. Feeding ecology of the Caucasian salamander (Mertensiella caucasica), with comments on life history. Asiatic Herpetol. Research, 4, 123-131.

Kuzmin, S.L. 1994. The problem of declining amphibian populations in the Commonwealth of Independent States and adjacent territories. Alytes, 12, 123-134.

Kuzmin, S.L. 1995. Clawed Salamanders of Asia. Westarp Wissenschaften.

Mezhzherin, S.V. 1992. A new species of green frog Rana terentievi sp. nova (Amphibia, Ranidae) from South Tajikistan. Doklady Akademii Nauk USSR, Matematicheskie, Estestvennye, Tekhnicheskie Nauki, (5), 154-157.

Orlova, V.F. and Tuniyev, B.S. 1989. On the taxonomy of the Caucasian common toads belonging to the group Bufo bufo verrucosissimus (Pallas) (Amphibia, Anura, Bufonidae). Bulleten Moskovskogo Obshchestva Ispytatelei, Otdel Biologicheskii. 94 (3), 13-24.

Pikulik, M.M. 1985. Zemnovodnye Belorussii. Nauka i Tekhnika, Minsk.

Szczerbak, N.N. 1966. Zemnovodyne $i$ Presmykayushchiesya Kryma. Naukova Dumka, Kiev.

Szczerbak, N.N. and Szczerban, M.I. 1980. Zemnovodnye i Presmykayushchiesya Ukrainskikh Karpat. Naukova Dumka, Kiev.

Talvi, T. 1992. Amphibians and reptiles of Estonia: list, geographic relationships and current situation. In Proceedings of the Sixth Ordinary General Meeting of the Societas Europaea Herpetologica, pp. 429-432, Budapest.

Tarkhnishvili, D.N. and Serbinova, I.A. 1993. The ecology of the Caucasian salamander (Mertensiella caucasica Waga) in a local population. Asiatic Herpetol. Research. 5, 147-165.

Vysotin, A.G. and Tertyshnikov, M.F. 1988. Amphibians of the Stavropol Province. In Zhivotnyi Mir Predkavkaziya i Sopredelnykh Territorii, pp. 87-121. Stavropol State University, Stavropol.

Sergius Kuzmin, Institute of Ecology and Evolution, Russian Academy of Sciences, Leninsky prospect 33, Moscow 117071, Russia. 